\title{
Effect of Various Concentration of Vegetable Protein in Hair Mask on the Hair Texture
}

\author{
Ivony Helen, Idajani Hadinoto, Lannie Hadisoewignyo, Lisa Soegianto \\ Fakultas Farmasi Unika Widya Mandala Surabaya \\ Jl. Dinoyo 42-44, Surabaya-60265
}

\begin{abstract}
Effect of various concentrations of vegetable protein in hair mask on the hair texture including hair smoothness, hair shining, hair strength, and morphology of hair had been studied. Concentrations of vegetable protein are made $5 \%, 7.5 \%$, and $10 \%$. The hair mask was evaluated such as organoleptic, $\mathrm{pH}$, viscosity, and allergy test. Hair mask used in six subjects that have damage hair for 8 times every 2 days. Then, the hair mask was evaluated such as hair smooth and hair shine that used tree trained panel and analyzed using non parametric method $\mathrm{Q}$ Cochran. Hair strength was evaluated using autograph then the results were analyzes using ANOVA test $(p<0.05)$, while hair morphology was evaluated using scanning microscope electron (SEM). The experimental results showed that vegetable protein in hair mask increased hair smoothness, hair strength, and morphology of damaged hair but did not give effect for hair shining. Various concentrations of vegetable protein $(5 \%, 7.5 \%$, and $10 \%)$ on hair mask given the same effect in hair texture (hair smoothness, hair strength, and hair morphology).
\end{abstract}

Keywords: vegetable protein, hair mask, hair texture

\section{INTRODUCTION}

The largest component of hair is protein, and the other are pigment melanin, lipids, water, trace elements such as $\mathrm{Cu}, \mathrm{Zn}, \mathrm{Ca}, \mathrm{Mg}$, and $\mathrm{Mn}$. When hair damage, most likely will be denatured proteins in the hair, either due to heating and chemical substances. For that, prior to having treatments such as hair curling, coloring, or after swimming, hair should be washed with a gentle shampoo, then treated with hair care (Mitsui, 1997). There are many different types of hair treatments offered include hair mask, hair spa, cream bath, and conditioner.

Hair mask can be used for hair care or special moisturizing hair and may consist of a vegetable based clay, the addition of a moisturizer or natural polymers (Baran, 1994). Hair mask can be used to restore strength and moisture to dry and damaged hair, so the hair becomes smooth, shiny, does not wrinkle, and has a good texture. Hair mask is generally made in cream o/w dosage form so easily washed with water.

The protein used in this study is vegetable protein, which is more widely used than animal protein. This is due to vegetable protein contains more amino acids needed to repair damaged hair that is cysteine and cystine, rather than animal protein (Nexxus, 2005). Vegetable proteins is also easier to get into the hair shaft (Kokopelli's Ltd., 2006). Vegetable protein commonly used such as soybean protein, wheat protein, corn protein and marine proteins.

The objective of this study was to formulate a hair mask with the addition of vegetable protein with different concentration, and then the influence of the concentration of vegetable protein in hair texture was observed.

\footnotetext{
*Corresponding author e-mail: lanhadi@yahoo.com
} 
The concentration of proteins that are commonly used for hair that is $2-10 \%$ (Cobiosa Industrial Asociadas SL, 2005), whereas protein concentrations commonly used in hair conditioner standard formula is $1-5 \%$ (Flick, 1989). For this study, vegetable protein used in concentrations of $5 \%, 7.5 \%$, and $10 \%$, because hair mask must have a higher protein content to improve the structure of hair, compared with hair conditioner which only keep moisture from the hair after shampooing.

Vegetable protein was used in this study is wheat protein because it can be easily absorbed by the hair and also can improve the branched hair (Snowdrift Farm Inc., 2004). In general, hair mask made in the form of o/w cream because it is more easily applied and easily rinsed (Mitsui, 1997). The parameters were observed of hair texture are the firmness or strength of hair, hair softness, shiny of hair, and hair morphology, including porosity of hair.

\section{METHODS}

\section{Materials}

Vegetable protein (Croda International Plc, North Humberside, UK), stearil alkohol (Merck, Germany), stearic acid (Shanghai Chemicals I/E Corp, China), hydrogenated lanolin (PT. Bratacochem, Indonesia), squalene (JPC Oil LTD, Worllingham), propylene glycol (Chemical, Pasific, Singapore), PEG 1500 (PT. Bratacochem, Indonesia), Tween 80 (JPC Oil LTD, Worllingham), glycerin monostearic (PT. Bratacochem, Indonesia), sodium metabisulphite (PT. Bratacochem, Indonesia), cetrimonium bromide (UENO, Tokyo, Japan).

\section{Equipments}

Autograph (Shimadzu AG-10 TE, Kyoto, Japan), scanning electron microscope (Jeol JSM P 100, Japan), digital analitycal balance (Sartorius AG Gottingen BL 2105, Germany), viscosimeter Brookfield (Mecomb tipe DV-1+ version 5.0, Singapura), and $\mathrm{pH}$ meter (Eutech Cybernetics tipe 500, Singapura).

\section{Formulation of Hair Mask}

Formulation employed in this study are summarized in Table I. Concentrations of vegetable protein are 5\%, 7.5\%, and 10\%. Each formula was made $250 \mathrm{~g}$.

Table I. Formulation of Hair Mask

\begin{tabular}{cccc}
\hline Ingredients & \multicolumn{3}{c}{ Percent } \\
\cline { 2 - 4 } & Formula A & Formula B & Formula C \\
\hline Vegetable Protein & 5 & 7,5 & 10 \\
Stearyl alcohol & 6 & 6 & 6 \\
Stearic acid & 2 & 2 & 2 \\
Hydrogenated lanolin & 4 & 4 & 4 \\
Squalene & 9 & 9 & 9 \\
Propylene glycol & 6 & 6 & 6 \\
PEG I500 & 4 & 4 & 4 \\
Tween 80 & 3 & 3 & 3 \\
Glicerin monostearic & 2 & 2 & 2 \\
Sodium metabisulphite & 0,05 & 0,05 & 0,05 \\
Setrimonium Br & 0,1 & 0,1 & 0,1 \\
Perfume & 0,2 & 0,2 & 0,2 \\
Water & 58,65 & 56,15 & 53,65 \\
\hline
\end{tabular}




\section{Preparation of Hair Mask}

Oil phase (stearyl alcohol, stearic acid, hydrogenated lanolin, squalene, and glycerin monostearat) was melt at a temperature above 70 ${ }^{\circ} \mathrm{C}$. Tween 80, PEG 1500, and propylene glycol were mixed together. Sodium metabisulphite and setrimonium $\mathrm{Br}$ dissolved in water and then mixed with the water phase and heated over a water bath until the temperature of $70{ }^{\circ} \mathrm{C}$. Oil phase was mixed into the water phase in a hot mortar, stirring quickly until the cream is formed and then cooled. Wheat protein is added to the cream while stirring until homogeneous.

\section{Organoleptic Test}

Organoleptic testing of hair mask used visually observed, including odor, color, shape and texture of product.

\section{pH Test}

$\mathrm{pH}$ test conducted to determine the $\mathrm{pH}$ of hair mask upon use does not cause skin irritation or other adverse effects. Weighed about $1 \mathrm{~g}$ of product and then added to $9 \mathrm{~mL}$ distilled water, stirred until homogeneous (Davis, 1977). pH test measured with a $\mathrm{pH}$ meter. Based on the $\mathrm{pH}$ of the market benchmark, the $\mathrm{pH}$ of hair mask that made was from 4.00 to 5.64 .

\section{Viscosity Test}

The viscosity is one determinant for consumption at the consumer feel comfortable. Starting from the ease of preparation out of the tube, until the viscosity level of hair mask is dependent of viscosity. Test of viscosity using a Brookfield Viscosimeter.

\section{Skin Irritation Test}

Preparations before applied to the hair, first allergy test to six subjects that are used hair mask on the skin behind the ear area is then covered with pads, after 24 hours seen whether itch or redness of the skin or do nothing.

\section{Efeect Test}

Each subject oiled hair mask as much as 5 $\mathrm{g}$ in the bound of hair with a diameter of $1.5 \mathrm{~cm}$, length $25 \mathrm{~cm}$ and divided to the front right side of the head smeared formula A, the left front of the head smeared formula B and from the center back of the head of $1 \mathrm{~cm}$ to the left, oiled formula $\mathrm{C}$, whereas for the control formula is applied to the side of the center back of the head of $1 \mathrm{~cm}$ to the left. Once applied to settling for \pm 15 minutes and then rinsed with three liters of water. Every subject in the treatment of 8 times every 2 days. After the last use of hair was observed smoothness, shine, strength, and morphology of hair.

\section{Hair Smoothing Test}

Hair smoothing test performed by 3 trained panelists in 6 subjects. Assessment criteria for the smoothness of the hair using a test that includes a smooth scoring (1) and rough (0). All the smoothness test results before treatment with a hair mask must meet the criteria for coarse hair (0), while the smoothness of the test results after treatment should meet the requirement of $75 \%$ for refined criteria (1), if it fulfills the new requirement to proceed with inter-test formula.

\section{Hair Shining Test}

Hair shining test performed by 3 trained panelists in 6 subjects. Observations were made on the hair after drying. Assessment criteria for using the test scoring luster hair covering hair is not attractive, not shiny and dry (1), shiny hair and glowing (2). All test results before treatment with hair glitter hair mask must meet the criteria (1), whereas the test results of hair luster after treatment should meet the requirement of $75 \%$ for criteria (2), if it fulfills the new requirement to proceed with inter-test formula.

\section{Hair Strength Test}

In the test hair strength Autograph-use tool with the workings of the first power source and accessories checked the appropriate tools. In the test hair strength used 6 trained panelists who all have damaged hair with hair strength range 0.2 to $0.8 \mathrm{kN}$, after the last usage is expected to increase in hair strength. Value the strength of hair after treatment to meet the range of normal hair strength value that is 0.95 to $1.4 \mathrm{kN}$. Hair strength before and after treatment was observed.

\section{Hair Morphology}

To see the morphology of hair, used Scanning Electron Microscope (SEM). Hair criteria to be used before treatment with a hair mask should meet the characteristics of damaged hair. Hair morphology test results have increased the quality of hair porosity when the test results equal or close to normal hair morphology. 


\section{Data Analysis}

The data obtained were tested statistically using SPSS for windows release 13.0.using Anova test, followed by test HSD (Honestly Significant Difference) if there are significant differences. Test the softness of hair was analyzed using non-parametric method Q Cochran test, using the following formula (Zar, 1984).

\section{RESULTS}

\section{Organoleptic Test}

The result of organoleptic test in Table II show that the hair mask meets the criteria specified that the hair mask should have creams o/w form, creamy, smooth texture, and smell fragrant.

Table II. Summary of organoleptic of Studied Hair Mask

\begin{tabular}{cccccc}
\hline & Spesification & & \multicolumn{3}{c}{ Formula } \\
\cline { 3 - 6 } Parameter & & A & B & C & Controlc) \\
\hline Odor & Fragrant & + a) & + b) & + & + \\
Color & Creamy & + & + & + & $-($ white $)$ \\
Dosage form & Cream & + & + & + & + \\
Texture & Soft & + & + & + & + \\
Emulsion type & o/w & + & + & + & + \\
Homogenity & Homogen & + & + & + \\
\hline a) required specification; ${ }^{\text {b) }}$ no specification preparation; ${ }^{\text {c) }}$ formula does not contain vegetable protein
\end{tabular}

pH Test

The result of $\mathrm{pH}$ test in Table III shows that the hair mask meets the criteria specified that the hair mask should have a $\mathrm{pH}$ range of 4-5.68 in accordance with the $\mathrm{pH}$ of three commercial hair masks of different brands and types. Formula control has a pH of $5.63-5.68$. This is due to be influenced by the $\mathrm{pH}$ of vegetable protein that has the acid $\mathrm{pH} 4.0-4.5$.

Table III. Summary of pH of Studied Hair Mask

\begin{tabular}{ccccc}
\hline Formula & Formula A & Formula B & Formula C & Control* \\
Replication & 4.69 & 4.67 & 4.66 & 5.68 \\
I & 4.68 & 4.66 & 4.66 & 5.68 \\
2 & 4.68 & 4.67 & 4.65 & 5.67 \\
3 & 4.68 & 4.67 & 4.66 & 5.68 \\
Mean & 0.007 & 0.007 & 0.035 & 0.028 \\
SD & & & &
\end{tabular}

*formula does not contain vegetable protein

\section{Viscosity Test}

Viscosity test results of hair mask as shown in Table IV shows that the preparations have been made to have the viscosity of 6320 -
$6620 \mathrm{cP}$. This shows that the preparation meets the criteria which the viscosity of a hair mask preparations have been made into the range brand hair mask on the market of $6080-6910 \mathrm{cP}$. 
Table IV. Summary of Viscosity (cP) of Studied Hair Mask

\begin{tabular}{ccccc}
\hline Formula & Formula A & Formula B & Formula C & Control* \\
\hline Replication & 6384 & 6530 & 6600 & 6500 \\
2 & 6480 & 6580 & 6500 & 6320 \\
3 & 6500 & 6500 & 6550 & 6460 \\
Mean & 6454.67 & 6536.67 & 6550 & 6426.67 \\
SD & 62.01 & 40.41 & 50.00 & 94.52 \\
\hline \multicolumn{5}{c}{ *formula does not contain vegetable protein }
\end{tabular}

\section{Skin Irritation Test}

Before the hair mask used by the subjects must be considered about the level of safety. For it, the irritation test results (Table V) showed that it does not cause irritation in the form of redness or itching of the skin subject concerned.

Table V. Summary of Skin Irritation Test of Studied Hair Mask

\begin{tabular}{ccccc}
\hline Subject & Formula A & Formula B & Formula C & Kontrol \\
\hline I & - & - & - & - \\
2 & - & - & - & - \\
3 & - & - & - & - \\
4 & - & - & - & - \\
5 & - & - & - & - \\
6 & - & $-=$ does not arise redness and itching of the skin; \\
& $+=$ arising from redness and itching of the skin
\end{tabular}

\section{Hair Smoothing Test}

In the $\mathrm{Q}$ Cochran statistic test there are significant differences in the smoothness of hair before and after treatment so continued with the multi comparisons which showed that there were no significant differences in hair smoothness between formula before treatment and after treatment (formula A. B and C) and there are significant differences between the formula control and before treatment (Table VI and VII).

\section{Hair ShiningTest}

The results of hair luster after treatment shows that in the formula $\mathrm{A}, \mathrm{B}, \mathrm{C}$, and control did not meet the requirements because less than $75 \%$ for criteria shiny hair with some bright light (Table VIII and IX).

Table VI. Summary of Hair Smoothing Test Before treatment

\begin{tabular}{|c|c|c|c|c|c|c|c|c|c|c|c|c|c|c|c|c|}
\hline \multirow{2}{*}{ Subject } & \multicolumn{4}{|c|}{ Formula A } & \multicolumn{4}{|c|}{ Formula B } & \multicolumn{4}{|c|}{ Formula C } & \multicolumn{4}{|c|}{ Kontrol } \\
\hline & $\mathbf{a}$ & b & C & $\bar{X}$ & $\mathbf{a}$ & b & C & $\bar{X}$ & $\mathbf{a}$ & b & c & $\bar{X}$ & $\mathbf{a}$ & b & c & $\bar{X}$ \\
\hline $\mathrm{I}$ & $\mathrm{I}$ & $\mathrm{I}$ & $\mathrm{I}$ & I & $\mathrm{I}$ & $\mathrm{I}$ & I & $\mathrm{I}$ & $\mathrm{I}$ & $\mathrm{I}$ & 1 & $\mathrm{I}$ & $\mathrm{I}$ & $\mathrm{I}$ & 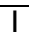 & $\mathrm{I}$ \\
\hline 2 & I & I & I & I & I & I & I & I & I & I & I & I & I & I & I & I \\
\hline 3 & I & I & I & I & I & I & I & I & I & I & I & I & I & I & I & I \\
\hline 4 & I & I & I & I & I & I & I & I & I & I & I & I & 0 & 0 & 0 & 0 \\
\hline 5 & I & I & I & I & I & I & I & I & I & I & I & & I & I & I & I \\
\hline 6 & I & I & I & I & I & I & I & I & I & I & I & I & 0 & 0 & 0 & 0 \\
\hline
\end{tabular}

$\mathrm{c}=$ the third panelis; $\bar{X}=$ mean 
Table VII. Summary of Hair Smoothing Test After treatment

\begin{tabular}{|c|c|c|c|c|c|c|c|c|c|c|c|c|c|c|c|c|}
\hline \multirow{2}{*}{ Subject } & \multicolumn{4}{|c|}{ Formula A } & \multicolumn{4}{|c|}{ Formula B } & \multicolumn{4}{|c|}{ Formula C } & \multicolumn{4}{|c|}{ Kontrol } \\
\hline & $\mathbf{a}$ & b & c & $\bar{X}$ & $\mathbf{a}$ & b & c & $\bar{X}$ & $\mathbf{a}$ & b & c & $\bar{X}$ & $\mathbf{a}$ & b & c & $\bar{X}$ \\
\hline 1 & 1 & 1 & 1 & 1 & 1 & 1 & 1 & 1 & 1 & 1 & 1 & 1 & 1 & 1 & 1 & 1 \\
\hline 2 & 1 & 1 & 1 & 1 & 1 & 1 & 1 & 1 & 1 & 1 & 1 & 1 & 1 & 1 & 1 & 1 \\
\hline 3 & 1 & 1 & 1 & 1 & 1 & 1 & 1 & 1 & 1 & 1 & 1 & 1 & 1 & 1 & 1 & 1 \\
\hline 4 & 1 & 1 & 1 & 1 & 1 & 1 & 1 & 1 & 1 & 1 & 1 & 1 & 0 & 0 & 0 & 0 \\
\hline 5 & 1 & 1 & 1 & 1 & 1 & 1 & 1 & 1 & 1 & 1 & 1 & & 1 & 1 & 1 & 1 \\
\hline 6 & 1 & 1 & 1 & 1 & 1 & 1 & 1 & 1 & 1 & 1 & 1 & 1 & 0 & 0 & 0 & 0 \\
\hline
\end{tabular}

$\mathrm{c}=$ the third panelis; $\bar{X}=$ mean

Table VIII. Summary of Hair Shining Test Before Treatment

\begin{tabular}{|c|c|c|c|c|c|c|c|c|c|c|c|c|c|c|c|c|}
\hline \multirow{2}{*}{ Subject } & \multicolumn{4}{|c|}{ Formula A } & \multicolumn{4}{|c|}{ Formula B } & \multicolumn{4}{|c|}{ Formula C } & \multicolumn{4}{|c|}{ Formula Control } \\
\hline & $\mathbf{a}$ & b & c & $\overline{\mathrm{X}}$ & $\mathbf{a}$ & B & c & $\overline{\mathrm{X}}$ & $\mathbf{a}$ & b & c & $\overline{\mathrm{x}}$ & $\mathbf{A}$ & b & c & $\overline{\bar{X}}$ \\
\hline 1 & 1 & 1 & 1 & 1 & 1 & 1 & 1 & 1 & 1 & 1 & 1 & 1 & 1 & 1 & 1 & 1 \\
\hline 2 & 1 & 1 & 1 & 1 & 1 & 1 & 1 & 1 & 1 & 1 & 1 & 1 & 1 & 1 & 1 & 1 \\
\hline 3 & 1 & 1 & 1 & 1 & 1 & 1 & 1 & 1 & 1 & 1 & 1 & 1 & 1 & 1 & 1 & 1 \\
\hline 4 & 1 & 1 & 1 & 1 & 1 & 1 & 1 & 1 & 1 & 1 & 1 & 1 & 1 & 1 & 1 & 1 \\
\hline 5 & 1 & 1 & 1 & 1 & 1 & 1 & 1 & 1 & 1 & 1 & 1 & 1 & 1 & 1 & 1 & 1 \\
\hline 6 & 1 & 1 & 1 & 1 & 1 & 1 & 1 & 1 & 1 & 1 & 1 & 1 & 1 & 1 & 1 & 1 \\
\hline
\end{tabular}

Table IX. Summary of Hair Shining Test After Treatment

\begin{tabular}{|c|c|c|c|c|c|c|c|c|c|c|c|c|c|c|c|c|}
\hline \multirow{2}{*}{ Subject } & \multicolumn{4}{|c|}{ Formula A } & \multicolumn{4}{|c|}{ Formula B } & \multicolumn{4}{|c|}{ Formula C } & \multicolumn{4}{|c|}{ Formula Control } \\
\hline & $\mathbf{a}$ & $\mathbf{b}$ & c & $\overline{\mathrm{X}}$ & $\mathbf{a}$ & B & $\mathbf{c}$ & $\overline{\mathrm{X}}$ & $\mathbf{a}$ & $\mathbf{b}$ & $\mathbf{c}$ & $\overline{\mathrm{X}}$ & $\mathbf{A}$ & $\mathbf{b}$ & c & $\overline{\mathrm{X}}$ \\
\hline 1 & 2 & 2 & 2 & 2 & 2 & 2 & 2 & 2 & 1 & 1 & 1 & 1 & 1 & 1 & 1 & 1 \\
\hline 2 & 2 & 2 & 2 & 2 & 2 & 2 & 2 & 2 & 2 & 2 & 2 & 2 & 2 & 2 & 2 & 2 \\
\hline 3 & 1 & 1 & 1 & 1 & 1 & 1 & 1 & 1 & 2 & 2 & 2 & 2 & 2 & 2 & 2 & 2 \\
\hline 4 & 1 & 1 & 1 & 1 & 1 & 1 & 1 & 1 & 1 & 1 & 1 & 1 & 1 & 1 & 1 & 1 \\
\hline 5 & 2 & 2 & 2 & 2 & 2 & 2 & 2 & 2 & 2 & 2 & 2 & 2 & 2 & 2 & 2 & 2 \\
\hline \multirow[t]{2}{*}{6} & 2 & 2 & 2 & 2 & 2 & 2 & 2 & 2 & 2 & 2 & 2 & 2 & 1 & 1 & 1 & 1 \\
\hline & \multicolumn{4}{|c|}{$66.6 \%$} & \multicolumn{4}{|c|}{$66.6 \%$} & \multicolumn{4}{|c|}{$66.6 \%$} & \multicolumn{4}{|c|}{$50 \%$} \\
\hline
\end{tabular}

$1=$ not shine and dry; 2 = shiny; $-\mathrm{a}=$ the first panelis; $\mathrm{b}=$ the second panelis; $\mathrm{c}=$ the third panelis; $\bar{x}=$ mean 


\section{Hair Strength Test}

In the paired t test hair strength difference before and after treatment. It was proved that the formula $\mathrm{A}, \mathrm{B}$, and $\mathrm{C}$ there are significant differences between the hair strength before and after treatment. While for the formula control there is no significant difference between the hair strength before and after treatment. Therefore, anova test followed by a strength difference of hair before and after treatment between the formula $\mathrm{A}, \mathrm{B}$, and $\mathrm{C}$ showed that there was no significant difference in strength between the hair on the before and after treatment between the formula $\mathrm{A}, \mathrm{B}$, and $\mathrm{C}$ (Table $\mathrm{X})$.

Table X. Paired $t$ Test and The Difference in Hair Strength Before and After Treatment

\begin{tabular}{cccccccccccccc}
\hline \multirow{2}{*}{ Subject } & \multicolumn{3}{c}{ Formula A } & \multicolumn{4}{c}{ Formula B } & \multicolumn{3}{c}{ Formula C } & \multicolumn{3}{c}{ Formula D } \\
\cline { 2 - 13 } & $\begin{array}{c}\text { Befor } \\
\text { e }\end{array}$ & After & $\Delta$ & Before & After & $\Delta$ & Before & After & $\Delta$ & $\begin{array}{c}\text { Befor } \\
\text { e }\end{array}$ & After & $\Delta$ \\
\hline I & 0.60 & 1.17 & 0.57 & 0.55 & 1.00 & 0.45 & 0.58 & 0.58 & 0 & 0.80 & 1.30 & 0.5 \\
2 & 0.80 & 1.10 & 0.30 & 0.55 & 1.17 & 0.62 & 0.50 & 1.08 & 0.58 & 0.62 & 0.62 & 0 \\
3 & 0.60 & 1.05 & 0.45 & 0.42 & 0.58 & 0.16 & 0.20 & 0.6 & 0.40 & 0.80 & 0.81 & 0.01 \\
4 & 0.80 & 1.30 & 0.50 & 0.62 & 1.40 & 0.78 & 0.80 & 1.32 & 0.52 & 0.60 & 1.00 & 0.40 \\
5 & 0.73 & 1.42 & 0.69 & 0.57 & 1.40 & 0.83 & 0.80 & 1.3 & 0.50 & 0.80 & 0.8 & 0 \\
6 & 0.80 & 1.17 & 0.37 & 0.70 & 1.05 & 0.35 & 0.40 & 0.75 & 0.35 & 0.80 & 0.8 & 0 \\
$\bar{X}$ & & & 0.48 & & & 0.53 & & & 0.40 & & 0.15 \\
SD & & & 0.14 & & & 0.26 & & & 0.21 & & & 0.23 \\
t scores & & & 8.40 & & & 5.02 & & & 4.59 & & 1.60 \\
\hline
\end{tabular}

\section{Hair Morphology}

On the morphology of hair test results before treatment (Figure 1) shows that the hair is damaged that can be seen from the branching hair. Imbrications open the cuticle cells and not large enough and looks neat coil keratin cells of the skin is dry and damaged hair (Kusumadewi, 2003) whereas in hair morphology test results after treatment (formula A, B, and C) showed that there was no branching and cracks in the hair (Figure 2,
3, and 4). Hair cuticle in good condition. Imbrications gap is also normal. Good texture and are arranged more neatly (Kusumadewi, 2003). On the morphology of hair test results after treatment with the formula control found that there are still cracks in the hair, rough texture and irregular, and there is also a loose cuticle cells (Figure 5). 


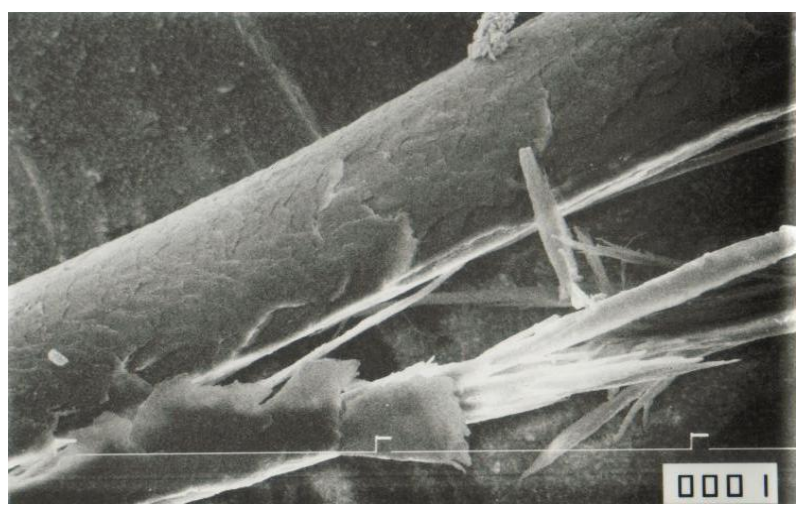

Figure I. SEM micrograph of hair before treatment

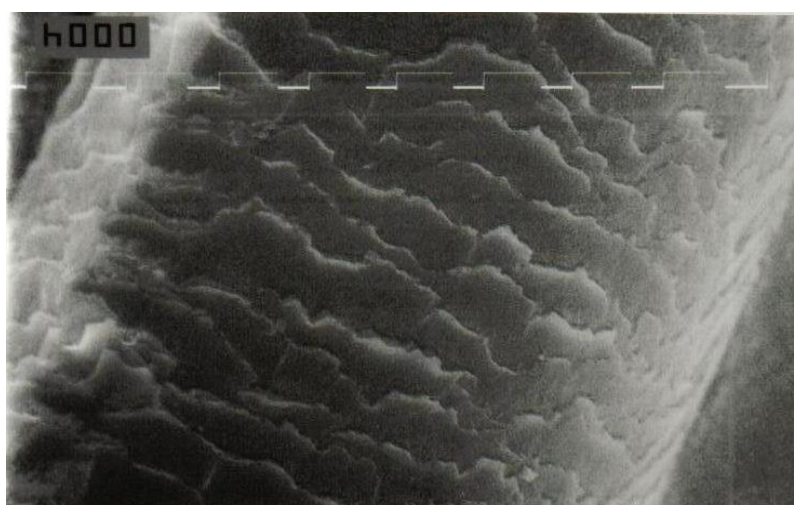

Figure 2. SEM micrograph of hair after treatment with formula A

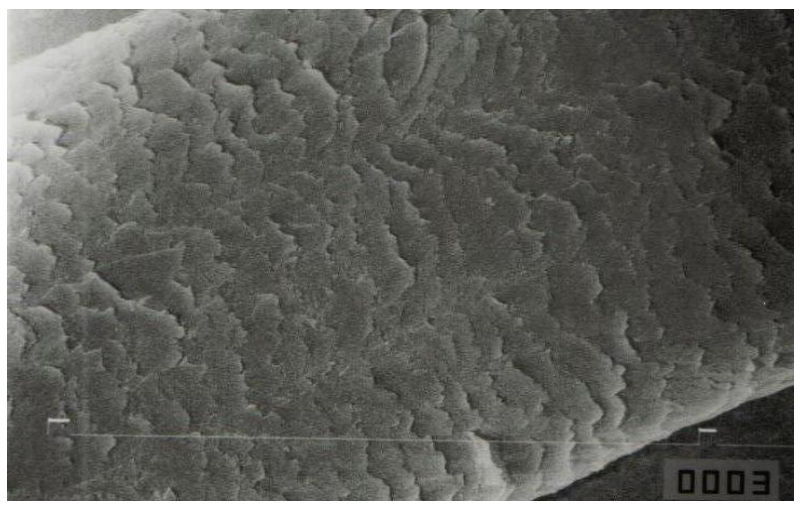

Figure 3. SEM micrograph of hair before treatment with formula B 


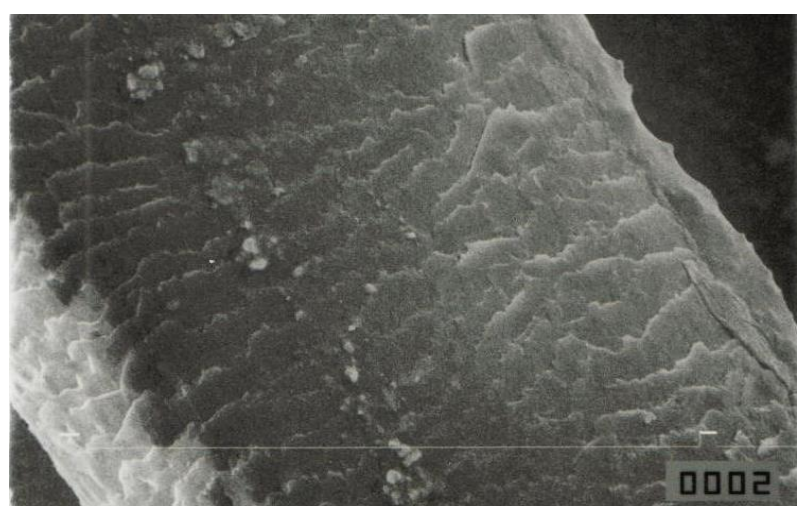

Figure 4. SEM micrograph of hair after treatment with formula $C$

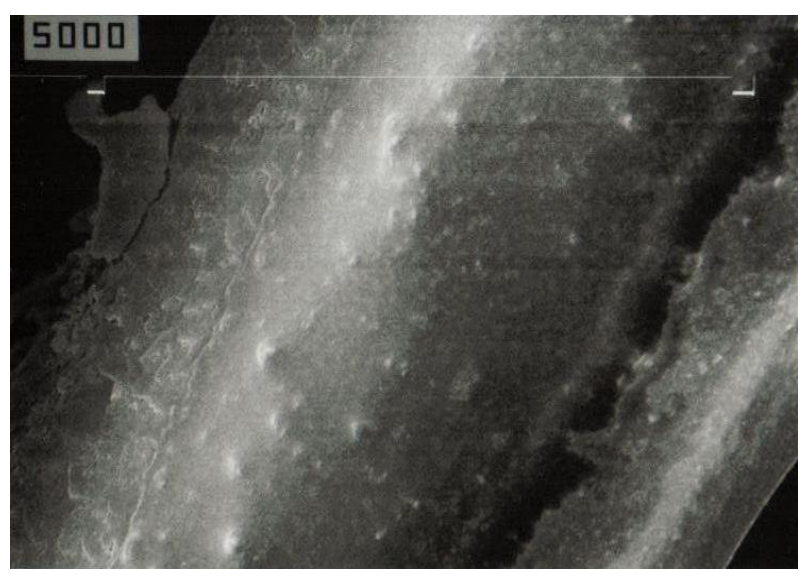

Figure 5. SEM micrograph of hair after treatment with control

\section{DISCUSSION}

Before use on the hair, the formula was evaluation that includes organoleptic, $\mathrm{pH}$, viscosity, and irritation testing. The result of organoleptic test showed that the hair mask made to have the form of o/w creams so easy to rinse, creamy, smooth texture, and fragrant. This suggests that all formula are expected to have met the criteria. In addition, $\mathrm{pH}$ and viscosity preparations have also been in accordance with existing sample in the market, and through irritation test proved that all of the hair mask formulas do not irritate the skin.

In the test hair smoothness, control formula can give the effect of smoothness to the hair compared with hair mask formula made in this study, this can happen because the control formula is a cream base that contains emollient (squalene) is quite high in the formula. There are significant differences in hair smoothness between the control formula and formulas after treatment (formula A, B, and C) so that although the base cream may affect the smoothness, but in the presence of vegetable protein can further increase the smoothness of hair. No increase in smoothness of hair from formula $\mathrm{A}, \mathrm{B}$, and $\mathrm{C}$, although the concentration of vegetable protein used increases, this is because vegetable protein is experiencing saturation so that a concentration of $5 \%$ (formula $\mathrm{A}$ ) is to provide the maximum smoothness so as to be able to see the influence of the concentration of vegetable protein to the 
smoothness of the hair can be seen at concentrations below $5 \%$.

All formulas were not made to improve the luster of hair so that should be added that can add luster hair dimethican example. All formulas can increase hair strength before and after treatment, this can happen because vegetable protein can improve hair texture as it can be directly attach themselves to the hair and fill in the crack and gaps. This strengthens the hair shaft, and repairs the split ends (Shai et al, 2001). Three concentrations of vegetable protein used no significantly different effect on the difference in hair strength before and after treatment.

\section{CONCLUSION}

Hair mask containing vegetable protein can increase the smoothness and the strength of hair and repair the morphology of hair damage, but it does not affect the luster of hair damaged. Increasing concentrations of vegetable protein $(5 \%, 7.5 \%$, and $10 \%)$ in the hair mask showed the same effect on hair texture (hair smoothness, hair strength, and hair morphology.

\section{REFERENCES}

Baran, M.O., 1994, Masks and Astrigents/Toners. In: Textbook of Cosmetic Dermatology, Banker, R. and Mailbach, I.H. (Ed), 2 nd ed. Martin Dunitz Ltd, London.

Cobiosa Industrial Asociadas SL. Biocollagen: 10 december 2005, Available at: http://www. cobiosa.com
Davis, M.H., 1977, Analysis of Cream and Lotions. In: New Burger's Manual of Cosmetic Analysis, Senzel A.J. (Ed.), 2 nd ed. Association of Official Analytical Chemists Inc., Washington.

Flick, E.W., 1989, Cosmetic and Toiletery Form. $2^{\text {nd }}$ ed. Noyes Inc., New Yersey, pp. 354484.

Kokopelli's Ltd. Natural \& Herbal Conditioners: 2 February 2006. Available at: http://www.kokogm.com/green market/co nditioner.html.

Kusumadewi, 2003, Rambut Anda Masalah, Perawatan dan Penataannya. Gramedia Pustaka Utama.

Mitsui, T., 1997. New Cosmetic Science. Elsevier Science B.V., Amsterdam, Netherlands.

Nexxus. Phytoorganik: Organic Natural Hair Care: 20 July 2005. Available at: http://nexxusproduct.com/stylist/pdf/produ ctdirectory.pdf.

Shai, A., Maibach, H.I. and Baran, R., 200I, Handbook of Cosmetic Skin Care. Martin Dunitz Ltd., London.

Snowdrift Farm Inc, How to Use Wheat Protein in Body, Skin and Hair Products: 2 February 2004, Available at: $<$ http://www.snowdriftfarm.com/form_wh eat .html>.

Zar, J.H., 1984, Biostatistical Analysis, $2^{\text {nd }}$ ed. Prentice Hall Inc. New Jersey. 